OAK

RIDGE

NATIONAL

LABORATORY

\title{
Radioisotope Distribution Program Progress Report for September 1979
}

E. Lamb

\section{UNION \\ CARBIDE}

\section{OPERATED BY}

UNION CARBIDE CORPORATION

FOR THE UNITED STATES

DEPARTMENT OF ENERGY
Access to the information in this report is limited to those indicated on the distribution list and to Department of Energy and Department of Energy Contractors 


\section{DISCLAIMER}

This report was prepared as an account of work sponsored by an agency of the United States Government. Neither the United States Government nor any agency Thereof, nor any of their employees, makes any warranty, express or implied, or assumes any legal liability or responsibility for the accuracy, completeness, or usefulness of any information, apparatus, product, or process disclosed, or represents that its use would not infringe privately owned rights. Reference herein to any specific commercial product, process, or service by trade name, trademark, manufacturer, or otherwise does not necessarily constitute or imply its endorsement, recommendation, or favoring by the United States Government or any agency thereof. The views and opinions of authors expressed herein do not necessarily state or reflect those of the United States Government or any agency thereof. 


\section{DISCLAIMER}

Portions of this document may be illegible in electronic image products. Images are produced from the best available original document. 
This report was prepared as an account of work sponsored by an agency of the United States Government. Neither the United States Government nor any agency thereof, nor any of their employees, contractors, subcontractors, or their employees, makes any warranty, express or implied, nor assumes any legal liability or responsibility for any third party's use or the results of such use of any information, apparatus, product or process disclosed in this report, nor represents that its use by such third party would not infringe privately owned rights. 


\section{ORNL/TM-7157}

Contract No. W-7405-Eng-26

Operations Division

RADIOISOTOPE DISTRIBITION PROGRAM

PROGRESS REPORT FOR SEPTEMBER 1979

E. Lamb

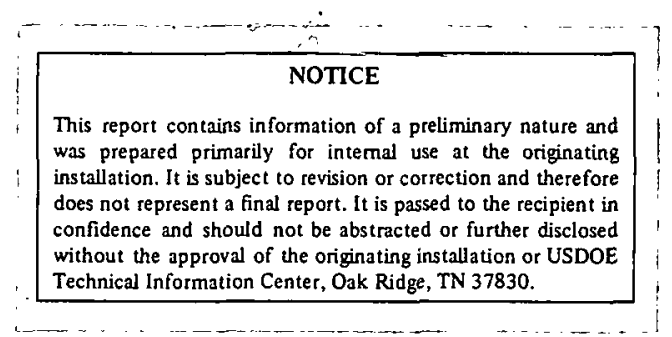

Work Sponsored by DOE Office of Health and

Environmental Research

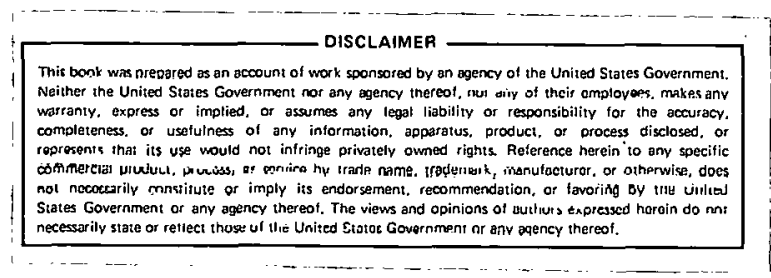

NOTICE This document contains information of a preliminary nature. It is subject to revision or correction and therefore does not represent a final repart.

OAK RIDGE NATIONAL LABORATORY

Oak Ridge, Tennessee 37830 operated by UNION CARBIDE CORPORATION

for the

DEPARTMENT OF ENERGY 


\section{THIS PAGE}

\section{WAS INTENTIONALLY \\ LEFT BLANK}


CONTENTS

Page

SUMMARY . . . . . . . . . . . . . . . . . . . I

RADIOISOTOPE PRODUCTION AND MATERIALS . . . . . . . . . . . 1

Reactor Products Production . . . . . . . . . . . . 1

Iridium-192 Production . . . . . . . . . . . . . . . I 1

Cyclotron Service Irradiations . . . . . . . . . . . . . I 1

Cesium-137 Production . . . . . . . . . . . . . . 1

Strontium-90 Production . . . . . . . . . . . . . . 2

Short-Lived Fission Production. . . . . . . . . . . . . 3

Krypton Enrichment Facility . . . . . . . . . . . . . 4

Tritium Operations . . . . . . . . . . . . . . 4

Krypton-85 Operations . . . . . . . . . . . . . 4

Packing and Shipping ................. 5

Alpha Handling Facility . . . . . . . . . . . . . 5

Miscellaneous . . . . . . . . . . . . . . . . 5

RADIOISOTOPE SALES . . . . . . . . . . . . . . . . 5

PUBLICATIONS . . . . . . . . . . . . . . . . . . 6 


\title{
RADIOISOTOPE DISTRIBUTION PROGRAM \\ PROGRESS REPORT FOR SEPTEMBER 1979
}

\author{
E. Lamb
}

Information is reported on new production inventory status, operational problems, and radioisotope sales.

\section{RADIOISOTOPE PRODUCTION AND MATERIALS}

Reactor Products Production (R. W. Schaich)

$\frac{\text { Processed Units }}{\frac{\text { Radioisotope }}{\text { Calcium-47 }}} \frac{\text { Amount (mCi) }}{15}$

Iridium-192 Production (R. W. Schaich)

Five customer irradiation units and ten ORNL HFIR units (RB) containing $114,000 \mathrm{Ci}$ of ${ }^{192} \mathrm{Ir}$ at HFIR discharge date were processed during the month of September, 1979. Seventeen shipments containing 90,000 Ci of ${ }^{192}$ Ir were made during this period.

\section{Cyclotron Service Irradiations (M. R. Skidmore)}

During September, 1979, the ORNL 86-Inch Cyclotron operated 5:35 hours for ORNL and Oak Ridge DOE Programs for total charges of $\$ 846$. Isotope Sales Inventory irradiations were 46 hours for total charges of $\$ 9,037$. Non-ORNL irradiations were $253: 15$ hours for total charges of $\$ 49,463$.

A cobalt-57 mun on September 4 was interrupted due to the failure of a high-current electrical cable in the high-voltage supply of the oscillator circuit. On September 11 the startup of a germanium-68 irradiation was delayed due to the failure of the refrigeration.system on the diffusion pump baffles. A gallium-67 run was intermpted for a routine check and exchange of the building electrical breaker. On September 25 a gold-195 irradiation was interrupted due to the shorting of the filament in the ion source.

Cesium-137 Production (R. W. Schaich)

Processing of two WESF containers of ${ }^{137} \mathrm{CsCl}(130,000 \mathrm{Ci})$ for AECL is in progress. Twenty-one teletherapy units (37,700 $\mathrm{Ci}$ ) were fabricated for AECL for shipment in september. The ${ }^{137} \mathrm{CsCl}$ product inventory follows: 
Product Inventory

(Decay calculated through August 31, 1979)

Inventory Material

Cesium-137 chloride powder

Total Inventory Material

Non-Inventory Material

Reject Pellets and Sources

Special Form Cans

Material returned or stored for custnmer

J. L. Shepherd

New England Nuclear Corporation

Fuerto Rico Sources

Lockheed

AE'CL powder

Radiation Resources

Ganma Industries

Minn. Mining \& Mfg. Company

Isomedix

Total Non-Inventory Material

TOTAL INVENTORY AND NON-INVENTORY MATERIAL
Amount ( $\mathrm{C} i$ )

$\frac{8,350}{8,350}$

9,050

3,900

60,700

1,500

7,500

18,800

6,600

12,300

8,000

9,900

50,000

188,250

196,600

Fabrication Summary

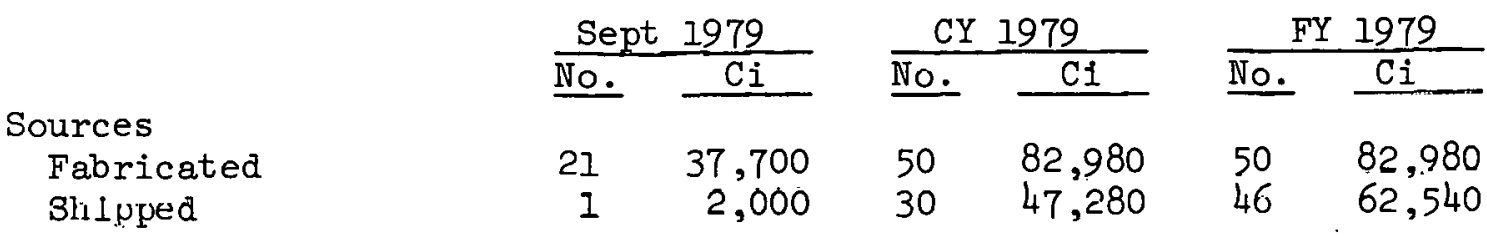

Special Form Cans

Fabriculed

Shipped

$\begin{array}{rrrrrr}0 & 0 & 0 & 0 & 0 & 0 \\ 1 & 100 & 10 & 2,810 & 12 & 4,810\end{array}$

Strontium-90 Production (R. W. Schaich)

The status of ${ }^{90} \mathrm{Sr}$ is given in the table which follows. 
Product Inventory

(Decay calculated through August 31, 1979)

Inventory Material

${ }^{90} \mathrm{Sr}$ titanate powder $( \pm 5 \%)$

Stock powder cans

Stock solution

Total Inventory Material

Amount (Ci)

Non-Inventory Material

${ }^{90} \mathrm{Sr}$ Fluoride

New England Nuclear Corporation

Calorimeter Standards

Weather Bureau Source

SNAP-7B

SNAP-7C

SNAP-7D

SNAP material purchase

Total Non-Inventory Material.

TOTAL INVENTORY AND NON-INVEIVTORY MATERIAL
0

2,850

170

3,020

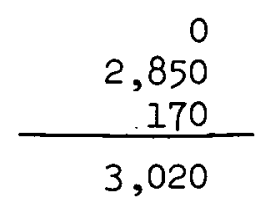

$$
\begin{array}{r}
68,500 \\
170 \\
3,800 \\
10,800 \\
148,800 \\
23,400 \\
136,100 \\
123,600 \\
\hline 515,170 \\
518,190
\end{array}
$$

\begin{tabular}{|c|c|c|c|c|c|}
\hline \multicolumn{2}{|c|}{ Sept. 1979} & \multicolumn{2}{|c|}{ CY 1979} & \multicolumn{2}{|c|}{ FY 1979} \\
\hline No. & $\overline{\mathrm{C} i}$ & No. & $\mathrm{Ci}_{i}$ & No. & $\mathrm{C}_{i}$ \\
\hline 0 & 0 & 0 & 0 & 4 & 153,000 \\
\hline 0 & 0 & 0 & 0 & 4 & 153,000 \\
\hline
\end{tabular}

Fabrication Summary

Sources

Fabricated

Shipped

Special Form Cans

Fabricated

Shipped
0

$0 \quad 0$

0

30
0

0

30

Short-Lived Fission Production (H. Bailey)

The Short=Tived Fission Product Facility operated normally during the report period. The following products were made available tor shipmenl:

Isotope

Xenon-133

Yttrium-91

Niobium-95

Strontium-89

Bur iün-140

Ruthenium-103

Ruthenium-106
Number of Batches

3

1

1

1

1

1

1
Amount (Ci)

2,000

13

17

20

10 
Krypton Enrichment Facility (J.R. DeVore)

The north bank of ${ }^{85} \mathrm{Kr}$ Thermal Diffusion Columns remains shut down as an energy conservation measure. During this report period, leak testing and repairs were continued on the north bank to place it in operation if additional capacity is required in the future.

Analysis results were received on the enriched ${ }^{85} \mathrm{Kr}$ removed from the columns last month.

\begin{tabular}{ccccc} 
Cylinder No. & $\frac{\text { \% Krypton }}{\%{ }^{85} \mathrm{Kr}}$ & Curies \\
\cline { 5 - 6 } HoKr-1000-19 & 99.61 & & 48.89 & 482 \\
HoKr-1000-17 & 99.70 & & 31.75 & 361 \\
HoKr-1000-21 & 99.17 & 30.72 & 294 \\
Total & & & 1137
\end{tabular}

The remainder of the material was tails analyzing $<3 \%{ }^{85} \mathrm{Kr}$. The above three cylinders represent the best material obtained to date and contain $60 \%$ of the total $\mathrm{C}$ column loading. The balance of the krypton on CD and $D$ columns was unloaded but has not been sampled. Unloading is $280 \%$ complete and should be completed in October.

Design of the enriched ${ }^{85} \mathrm{Kr}$ storage and sampling system is approximately $98 \%$ complete. Removal of the old $85_{\mathrm{Kr}}$ storage equipment has been completed. Installation of a new storage and sampling system is scheduled to start in October, 1979.

\section{Tritium Operations ( $J$. R. DeVore)}

The piping and instrumentation portions of the tritium handling system have not been completed. Processing piping is the primary holdup. The instrumentation is essentially complete with the exception of one flowmeter which is waiting for process piping to specify the flow range. Fabrication of the hoods has been initiated and a capital work order issued to purchase instrumentation.

Eleven gas cylinders and 10 non-returnable containers were loaded with $126,000 \mathrm{Ci}$ of tritium for shipment to customers.

Krypton-85 Operations (J.R. DeVore)

Fourteen gas cylinders were loaded with $720 \mathrm{Ci}$ of ${ }^{85} \mathrm{Kr}$ for shipment to customers. 
Packing and Shipping (R. D. Johnston)

One hundred and eighty-three packages were processed and shipped during the reporting period. The total weight shipped was 88,000 pounds.

\begin{tabular}{|c|c|c|c|c|}
\hline $\begin{array}{l}\text { Radioactive } \\
\text { olid Shipments }\end{array}$ & $\begin{array}{l}\text { Radioactive } \\
\text { Gas Shipments }\end{array}$ & $\begin{array}{l}\text { Radioactive } \\
\text { Liquid Shipments }\end{array}$ & $\begin{array}{c}\text { Empty } \\
\text { Containers }\end{array}$ & Total \\
\hline
\end{tabular}

72

57

38

16

183

Alpha Handling Facility (R. D. Johnston)

Four packages of alpha-emitting material were prepared for shipment--one $0.10 \mathrm{~g}$ shipment of $243 \mathrm{Am}$, one $2.24 \mathrm{~g}$ package of ${ }^{238} \mathrm{Pu}$, and two packages total.jing $17.0 \mathrm{~g}$ of ${ }^{237} \mathrm{~Np}$.

Miscellaneous (R. W. Schaich)

The fabrication of 23 new containers for use in the ${ }^{85} \mathrm{Kr}$ and tritium business is $275 \%$ complete. Delivery is now scheduled for December, 1979.

Fabrication of a new tritium cylinder decontamination station was completed in the Plant and Equipment shops. Installation of this station is scheduled for October, 1979.

\section{RADIOISOTOPE SALES}

\section{J. E. Ratledge}

Shipments made during the month that may be of interest are listed below:

Customer

Isotope

Large Quantities

Battelle Northwest

Japan Radioisotope Association

Trio. Tech International

Georgetown Univ. Medical Center

The Radiochemical Centre Ltd.

Brandhurst Company, Ltd.

Univ, of California, LLL

ICN Pharmaceuticals

New England Nuclear

Radium Chemie

Saunders Roe Dev. Ltd.

Self-Powered Lighting Ltd.

TII Ind. Inc.

United States Radium Corp.
Krypton-85

Krypton-85

Krypton-85

Cesium-137

Promethium-147

Tritium

Tritium

Tritium

Tritium

Tritium

Tritium

Tritium

Tritium

Tritium
Amount

$$
\begin{array}{r}
100 \mathrm{Ci} \\
100 \mathrm{Ci} \\
250 \mathrm{Ci} \\
2,000 \mathrm{Ci} \\
10,450 \mathrm{Ci} \\
30,000 \mathrm{Ci} \\
3,694 \mathrm{Ci} \\
2,000 \mathrm{Ci} \\
8,000 \mathrm{Ci} \\
10,000 \mathrm{Ci} \\
30,000 \mathrm{Ci} \\
8,000 \mathrm{Ci} \\
1,500 \mathrm{Ci} \\
15,000 \mathrm{Ci}
\end{array}
$$


Customer

Isotope

Amount

Withdrawn Items

Mallinckrodt Nuclear

ORNL, Dept. of Quality Assurance and Inspection

ORNL, Chemical Technology
Selenium-75

Iodine-131

Iodine-131
$2,500 \mathrm{mCi}$

$60 \mathrm{mCi}$

$8 \mathrm{mCi}$

Items Used in Cooperative Programs

University of Kentucky

Platinum-195m

$10 \mathrm{mCi}$

The radioisotope sales and shipments for the twelve months of fiscal year 1978 and fiscal year 1979 are given in Table 1.

Table 1. Radiolsotope Sales and Shipments

\begin{tabular}{lrr}
\hline \multicolumn{1}{c}{ Item } & $\begin{array}{c}10 / 1 / 77 \text { through } \\
9 / 30 / 78\end{array}$ & $\begin{array}{c}10 / 1 / 78 \text { through } \\
9 / 30 / 79\end{array}$ \\
\hline Inventory Items & $\$ 128,592$ & $\$ 1284,191$ \\
$\quad$ Tritium & $1,732,537$ & $1,831,471$ \\
Major Products $\quad 574,351$ & 472,271 \\
$\quad$ Iridium-192 & $1,120,639$ & $1,540,204$ \\
Radioisotope Services & 29,007 & 391,527 \\
Cyclotron Irradiations & 369,847 & 477,923 \\
Miscellaneous Processed Materials & 237,417 & 69,273 \\
Packing and Shipping & 222,730 & 180,395 \\
& $\$ 4,681,120$ & $\$ 5,247,255$ \\
& 2,647 & 2,079
\end{tabular}

\section{PUBL ICAT IONS}

\section{Repurls}

E. Lamb, Radioisotope Distribution Program Progress Report for August, 2979, ORNL/TM-7088 (October, 1979). 
ORNL/TM-7157

INTERNAL DISTRIBUTION
1. F. N. Case
2. W. R. Casto
3. J. A. Cox
4. P. W. Hembree
5. R. F. Hibbs
6. F. F. Knapp
7. E. Lamb
8. B. F. Maskewitz, RSIC
9. C. L. Ottinger
10. H. Postma

1I. M. E. Ramsey

12. J. E. Ratledge

13. C. R. Richmond

14. R. W. Schaich

15. M. R. Skidmore

16. M. J. Skinner

17-18. Central Research Library

19-20. Laboratory Records Department

21. Laboratory Records - RC

22. Document Reference Section

\section{EXTERNAL DISTRIBUTION}

23. J. N. Maddox, DOE-EV, Washington, DC

24. H. A. O'Brien, LASL, Los Alamos, New Mexico

25. L. D. Perrigo, PNL, Richland, Washington

26. L. G. Stang, Jr., BNL, New York

27. H. H. Van Tuyl, PNL, Richland, Washington

28. W. H. Weyzen, DOE-OHER, Washington, DC

29. Donner Laboratory Library, Univ. of California, Berkeley, CA

30. Assistant Manager for Energy Research and Development, DOE-ORO

31-32. Technical Information Center 